\title{
Contribution of Non-renal Clearance to the Elimination of Vancomycin during Repeated Intravenous Administration in Elderly Patients
}

\author{
Toshihiro CHO*1 Eiji UCHIDA*1 Takayoshi OGUMA*2 \\ Naoki UCHIDA*1 Kuninobu YASUDA*1 $^{* 1}$ Ken SHIMADA*1 \\ Shinichi KOBAYASHI*3 and Hajime YASUHARA*1
}

(Received on January 23, 1995) (Express)

*1 Department of Pharmacology, School of Medicine, Showa University
1-5-8 Hatanodai, Shinagawa-ku, Tokyo 142, Japan
${ }^{* 2}$ Developmental Research Laboratories, Shionogi and Co., Ltd.
${ }^{* 3}$ Department of Pharmacology, St. Marianna University School of Medicine

In order to clarify vancomycin pharmacokinetics in a Japanese elderly population, vancomycin $(10 \mathrm{mg} / \mathrm{kg})$ was repeatedly administered to 6 elderly female patients with methicillin-resistant Staphylococcus aureus (MRSA) infections (age $78.3 \pm 5.9$ years, weight $34.8 \pm 9.4 \mathrm{~kg}, \mathrm{CL}_{\mathrm{CR}} 41.9 \pm 19.8 \mathrm{ml} / \mathrm{min}$, mean $\pm \mathrm{SD}$ ) by 1-hour constant infusion for 6 days. Vancomycin was given to elderly patients once on day 1 and 6 , and twice on day 2 to day 5 at 12 -hour intervals. Six healthy male volunteers (age $22.0 \pm 1.7$ years, weight $62.7 \pm 7.5 \mathrm{~kg}, \mathrm{CL}_{\mathrm{CR}} 115.0 \pm 9.6 \mathrm{ml} / \mathrm{min}$, mean $\pm \mathrm{SD}$ ) were administered vancomycin once by 1-hour infusion. Serum and urinary vancomycin concentrations were measured by fluorescence polarization immunoassay and bioassay, respectively. Total clearance (CL) of vancomycin was $95.50 \pm 15.74 \mathrm{ml} / \mathrm{min}$ in the healthy control group subjects, while the value of $\mathrm{CL}$ was $35.21 \pm 13.29 \mathrm{ml} / \mathrm{min}$ in the elderly patients on 1st day. In elderly patients, vancomycin was substantially eliminated extrarenally in comparison with the healthy subjects. Pharmacokinetic parameters were compared between day 1 and day 6 in the elderly patients. Non-linear pharmacokinetics was observed during multiple administration, $\mathrm{t}_{1 / 2}$ was prolonged from $12.99 \pm 7.11$ to $21.95 \pm 12.00$ hour on day $6(\mathrm{p}<0.05)$. CL significantly decreased from $35.21 \pm 13.29$ to $23.64 \pm 8.50 \mathrm{ml} / \mathrm{min}$ on day $6(\mathrm{p}<0.05)$. In contrast, renal clearance of vancomycin $\left(\mathrm{CL}_{\mathrm{R}}\right)$ remained constant throughout the study $(15.06 \pm 5.86$ and $17.76 \pm 7.78 \mathrm{ml} / \mathrm{min}$ on day 1 and day 6 , respectively). The ratio of nonrenal clearance $\left(\mathrm{CL}_{\mathrm{NR}}\right)$ to $\mathrm{CL}$ was decreased from 0.568 (mean) to 0.268 after multiple dosing of vancomycin. The results suggested that vancomycin was eliminated mainly extrarenally in the elderly patients and that this extrarenal elimination was reduced during the repeated administration. These findings may have clinical implications for the long-term treatment of elderly patients with MRSA infections.

Key words : vancomycin, elderly patients, long-term treatment, non-renal clearance

${ }^{* 1}$ 昭和大学医学部薬理 $\bar{\top} 142$ 東京都品川区旗の台 1-5-8

*2 塩野義製薬 (株) 新薬研究所 $* 3$ 聖マリアンナ医科大学薬理 


\section{Introduction}

Vancomycin, a glycopeptide antibiotic, was isolated from Streptomyces orientalis. In the USA and Europe, intravenous vancomycin administration has been widely used for methicillin-resistant Staphylococcus aureus (MRSA) infections, and superior efficacy of this drug has been established.

Although in Japan vancomycin was only used orally for antibiotic prophylaxis of bone marrow transplant recipients and for treatment of Clostridium difficile pseudomembranous colitis, intravenous vancomycin has recently been approved for the treatment of MRSA infections. Vancomycin was reported not to be metabolized in the liver but to be excreted unchanged into the urine $(80 \sim 100 \% \text { of intravenous dose })^{1)}$. Accordingly, accumulation of vancomycin occurs in patients with renal functional impairment and dosage adjustment is necessary in these patients to avoid adverse events associated with an elevated serum vencomycin concentration $^{2,3)}$. Renal function is known to decline with age and to be especially reduced in the elderly. Therefore the pharmacokinetics of the drug in this population must be clarified to substantiate dosage recommendations. The purpose of this study was to investigate the pharmacokinetics of repeated administrations of intravenous vancomycin in elderly patients.

\section{Methods}

\section{Subjects}

Patients were 6 female inpatients with MRSA infections (age $78.3 \pm 5.9$ years, weight $34.8 \pm 9.4 \mathrm{~kg}, \mathrm{CL}_{\mathrm{CR}} 41.9 \pm 19.8 \mathrm{ml} / \mathrm{min}$, mean \pm SD) (Table 1). No significant abnormalities were found on blood and biochemical screening and electrocardiogram. The patients gave informed consent for participation in this study
Tab. 1 Profile of Elderly Patients

\begin{tabular}{cccccc}
\hline No. & $\begin{array}{c}\text { Age } \\
(\mathrm{yr})\end{array}$ & Gender & \multicolumn{2}{c}{ B. W. } & \multicolumn{2}{c}{$\mathrm{CL}_{\mathrm{CR}}(\mathrm{ml} / \mathrm{min})$} \\
& & Before & After \\
\hline 1 & 84 & Female & 26 & 19.3 & 28.1 \\
2 & 87 & Female & 34 & 21.0 & 21.8 \\
3 & 73 & Female & 50 & 34.4 & 36.0 \\
4 & 78 & Female & 30 & 51.3 & 59.5 \\
5 & 74 & Female & 42 & 62.6 & 47.5 \\
6 & 74 & Female & 27 & 62.7 & 66.6 \\
\hline Mean & 78.3 & & 34.8 & 41.9 & 43.3 \\
SD & 5.9 & & 9.4 & 19.8 & 17.7 \\
\hline
\end{tabular}

$\mathrm{CL}_{\mathrm{CR}}$ : creatinine clearance ;

Before: before treatment; After: after treatment

in the presence of a witness who wrote the signature on the report form of the consent. As a reference group, 6 young healthy male volunteers (age $22.0 \pm 1.7$ years, weight $62.7 \pm 7.5 \mathrm{~kg}$, $\mathrm{CL}_{\mathrm{CR}} 115.0 \pm 9.6 \mathrm{ml} / \mathrm{min}$, mean $\pm \mathrm{SD}$ ) were recruited for single intravenous administration of vancomycin. All volunteers received a full medical examination and all gave written, informed consent before entry into the study. The protocol of this study was approved of by the Institutional Review Board (IRB) of the Showa University Hospital.

\section{Study Design and Protocol}

The patients received $10 \mathrm{mg} / \mathrm{kg}$ of vancomycin intravenously over 60-minute for 6 days. Vancomycin was infused once on day 1 and on day 6 , and twice daily between day 2 and 5 , using a mechanical infusion pump (Terumo, STC 503) in order to compare the vancomycin pharmacokinetics after a single dose with those after repeated administration. Except for other antibiotics, the patients took their routine oral medicines every day. Serum samples were obtained before the start of vancomycin infusion and at 1, 1.5, 2, 4, 6, 12 and 24 hours after the start of the drug administration on day 1 
and day 6 . Between days 2 and 5, samples were obtained before the start of infusion and 1 hour after the end of infusion. Urine was collected every 24-hour from the start of 1st infusion to 96 hour after the last (10th) infusion. Serum protein binding of vancomycin was determined at 1 and 4 hour after the start of infusion on day 1 and day 6 by means of ultrafiltration using MPS-3 (Amicon, Danvers, MA. USA).

For healthy subjects, the same dosage of vancomycin $(10 \mathrm{mg} / \mathrm{kg})$ as in the elderly patients was administered intravenously for 1hour using an infusion pump. Serum samples were obtained before infusion and at 1, 1.5, 2, 3, $4,6,8,12$ and 24 hours after the start of the infusion. Urine was collected for the time period $0 \sim 2,2 \sim 4,4 \sim 6,6 \sim 8,8 \sim 12,12 \sim 24,24$ $\sim 48$, and $48 \sim 72$ hours after the start of infusion. Serum protein binding was measured at the same time points as in the elderly patients.

\section{Assay Method}

Serum vancomycin concentrations were determined with fluorescence polarization immunoassay procedure (TDx : Abbott Laboratories, Diagnostics Division, Irving, TX. USA). The coefficients of variation of this method were less than $3 \%, 3 \%$ and $5 \%$ for the intrarun, the interrun and the intra-assays, respectively. The detection limit was $1 \mu \mathrm{g} / \mathrm{ml}$.

Vancomycin concentrations in urine were measured by a band culture bioassay using Bacillus subtilis ATCC 6633 as the test organism. The intrarun and the interrun coefficients of variation were less than $4 \%$ and $5 \%$, respectively, with sensitivity limit of $0.2 \mu \mathrm{g} / \mathrm{ml}$.

\section{Pharmacokinetic Analysis}

Serum concentrations of vancomycin were analyzed by least-squares regression technique using a two-compartment model to estimate the pharmacokinetic parameters as shown below :

$\mathrm{k}_{12}$ : Transfer rate constant from the central to a peripheral compartment

$\mathrm{k}_{21}$ : Transfer rate constant from a peripheral to the central compartment

$\mathrm{k}_{10}$ : Elimination rate constant from the central compartment

$\mathrm{Vc}$ : The apparent volume of the central compartment

Using these parameters, $t_{1 / 2}$, AUC, and total clearance $(\mathrm{CL})$ were calculated as follows:

$\lambda_{\mathrm{z}}=$

$$
\frac{\mathrm{k}_{12}+\mathrm{k}_{21}+\mathrm{k}_{10}-\sqrt{\left(\mathrm{k}_{12}+\mathrm{k}_{21}+\mathrm{k}_{10}\right)^{2}-4 * \mathrm{k}_{21} * \mathrm{k}_{10}}}{2}
$$

$\mathrm{t}_{1 / 2}=\ln 2 / \lambda_{\mathrm{z}}$

AUC $=$ Dose $/ \mathrm{CL}$

$\mathrm{CL}=\mathrm{VC} * \mathrm{k}_{10}$

Renal clearance $\left(\mathrm{CL}_{\mathrm{R}}\right)$ was calculated using unchanged drug recovered in urine $(\mathrm{Ae})$, as follows :

$\mathrm{CL}_{\mathrm{R}}=\mathrm{Ae}_{(0 \rightarrow 24 \mathrm{hr})} / \mathrm{AUC}_{(0 \rightarrow 24 \mathrm{hr})}$

Non-renal clearance $\left(\mathrm{CL}_{\mathrm{NR}}\right)$ was defined as: $\mathrm{CL}_{\mathrm{NR}}=\mathrm{CL}-\mathrm{CL}_{\mathrm{R}}$

\section{Statistical Analysis}

Wilcoxon Matched-pairs Signed-ranks Test was applied for the evaluation of the pharmacokinetic difference in elderly patients between 1 st dose and the last dose. The statistical significance level was set at $\alpha=0.05$, and the results are reported as mean $\pm \mathrm{SD}$, unless stated otherwise.

\section{Results}

All subjects completed the study. No adverse events or abnormalities of clinical laboratory tests including blood and biochemical screening, urinalysis, and ECG were observed during the study. 
Tab. 2 Pharmacokinetic Parameters of Vancomycin in Healthy Volunteers

\begin{tabular}{ccrcrrr}
\hline Subject & $\begin{array}{c}\mathrm{t}_{1 / 2} \\
(\mathrm{hr})\end{array}$ & \multicolumn{1}{c}{$\begin{array}{c}\mathrm{Vc} \\
(\mathrm{L})\end{array}$} & $\begin{array}{c}\mathrm{AUC} \\
(\mu \mathrm{g} \cdot \mathrm{hr} / \mathrm{ml})\end{array}$ & $\begin{array}{c}\mathrm{CL} \\
(\mathrm{ml} / \mathrm{min})\end{array}$ & $\begin{array}{c}\mathrm{CL}_{\mathrm{R}} \\
(\mathrm{ml} / \mathrm{min})\end{array}$ & $\mathrm{CL}_{\mathrm{R}} / \mathrm{CL}$ \\
\hline 1 & 2.43 & 10.24 & 101 & 127.05 & 111.05 & 0.87 \\
2 & 3.37 & 9.02 & 105 & 87.07 & 77.70 & 0.89 \\
3 & 2.80 & 7.62 & 112 & 89.41 & 82.70 & 0.92 \\
4 & 2.98 & 9.83 & 112 & 94.20 & 91.29 & 0.97 \\
5 & 3.35 & 9.33 & 111 & 91.12 & 90.47 & 0.99 \\
6 & 2.95 & 8.04 & 118 & 84.96 & 81.42 & 0.96 \\
\hline Mean & 2.98 & 9.01 & 110 & 95.64 & 89.11 & 0.93 \\
SD & 0.35 & 1.02 & 6 & 15.72 & 11.99 & 0.05 \\
\hline
\end{tabular}

$t_{1 / 2}:$ terminal serum half-life ; Vc: the apparent volume of the central compartment ; AUC : area under the concentration-time curve ; $\mathrm{CL}$ : total clearance of vancomycin ; $\mathrm{CL}_{\mathrm{R}}$ : renal clearance of vancomycin; $\mathrm{CL}_{\mathrm{R}} / \mathrm{CL}$ : the ratio of the renal clearance to the total clearance

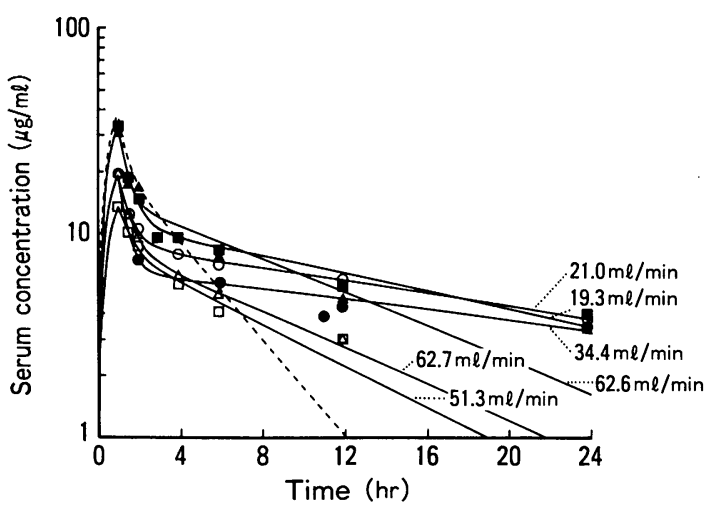

Fig. 1 Individual serum concentration-time curves of vancomycin for 6 elderly patients after the 1st administration. The dashed line shows the mean curve in 6 healthy subjects as a reference.

\section{Pharmacokinetic Analysis in Healthy Subjects}

Pharmacokinetic parameters of vancomycin after 1-hour infusion in healthy subjects are shown in Table 2 . The average $t_{1 / 2}$ was $2.98 \pm$ $0.35 \mathrm{hr}$. Mean apparent volume of distribution was $9.01 \pm 1.02 \mathrm{~L}$. Total of $85.3 \pm 3.8 \%$ (range $79.7 \sim 89.9 \%$ ) of the dose was recovered in urine during 24 hours. CL of vancomycin was $95.64 \pm$
$15.72 \mathrm{ml} / \mathrm{min}$ and $\mathrm{CL}_{\mathrm{R}} 89.11 \pm 11.99 \mathrm{ml} / \mathrm{min}$. The ratio of $\mathrm{CL}_{R}$ to $\mathrm{CL}$ was $0.93 \pm 0.05$ indicating that the major elimination route of vancomycin in healthy subjects was renal excretion.

\section{Serum Concentrations of Vancomycin in Elderly Patients on Day 1}

The individual serum concentration-time curves of vancomycin in 6 elderly patients on the 1st administration are shown in Figure 1. The peak serum concentration $\left(\mathrm{C}_{\max }\right)$ was obtained at the end of the infusion and the mean $\mathrm{C}_{\max }$ was $22.6 \pm 7.8 \mu \mathrm{g} / \mathrm{ml}$ (range 13.4 33.4 $\mu \mathrm{g}$ / $\mathrm{ml}$ ). As compared with the fitted curve of mean plasma concentration of the healthy volunteers (dashed line), a marked delay of vancomycin elimination was observed in the elderly. The mean percentage of the dose excreted in urine was $32.6 \pm 8.3 \%$ (range $23.2 \sim 46.1 \%$ ) in elderly patients during the first 24 hours of day 1 .

\section{Pharmacokinetic Analysis in the Elderly Patients}

Pharmacokinetic parameters of vancomycin in the elderly patients estimated from the 1st (day 1) and the 10th (day 6) administrations 
Tab. 3 Pharmacokinetic Parameters of Vancomycin in Elderly Patients

\begin{tabular}{|c|c|c|c|c|c|c|c|c|}
\hline $\begin{array}{l}\text { Dose } \\
\text { No. }\end{array}$ & Subject & $\begin{array}{l}t_{1 / 2} \\
(h r)\end{array}$ & $\begin{array}{l}\mathrm{Vc} \\
(\mathrm{L})\end{array}$ & $\begin{array}{c}\text { AUC } \\
(\mu \mathrm{g} \cdot \mathrm{hr} / \mathrm{ml})\end{array}$ & $\begin{array}{c}\mathrm{CL} \\
(\mathrm{ml} / \mathrm{min})\end{array}$ & $\begin{array}{c}\mathrm{CL}_{\mathrm{R}} \\
(\mathrm{ml} / \mathrm{min})\end{array}$ & $\begin{array}{c}\mathrm{CL}_{\mathrm{NR}} \\
(\mathrm{ml} / \mathrm{min})\end{array}$ & $\mathrm{CL}_{\mathrm{NR}} / \mathrm{CL}$ \\
\hline \multirow{8}{*}{$1 s t$} & 1 & 23.06 & 6.34 & 239 & 18.10 & 8.07 & 10.03 & 0.554 \\
\hline & 2 & 19.16 & 11.22 & 257 & 22.07 & 9.43 & 12.64 & 0.573 \\
\hline & 3 & 13.63 & 8.25 & 248 & 33.65 & 17.22 & 16.43 & 0.488 \\
\hline & 4 & 7.43 & 9.81 & 96 & 52.37 & 21.01 & 31.36 & 0.599 \\
\hline & 5 & 7.33 & 5.88 & 177 & 39.90 & 12.81 & 27.09 & 0.679 \\
\hline & 6 & 6.76 & 8.37 & 100 & 45.17 & 21.83 & 23.34 & 0.517 \\
\hline & Mean & 12.99 & 8.31 & 186 & 35.21 & 15.06 & 20.15 & 0.568 \\
\hline & $\mathrm{SD}$ & 7.11 & 2.03 & 74 & 13.29 & 5.86 & 8.45 & 0.067 \\
\hline \multirow{8}{*}{10 th } & 1 & 42.66 & 6.76 & 368 & 11.78 & 7.52 & 4.26 & 0.362 \\
\hline & 2 & 27.92 & 13.60 & 364 & 15.57 & 10.49 & 5.08 & 0.326 \\
\hline & 3 & 22.84 & 10.50 & 339 & 24.55 & 17.31 & 7.24 & 0.295 \\
\hline & 4 & 13.68 & 6.90 & 151 & 33.15 & 24.16 & 8.99 & 0.271 \\
\hline & 5 & 12.00 & 6.30 & 223 & 31.50 & 27.82 & 3.68 & 0.117 \\
\hline & 6 & 12.60 & 6.10 & 178 & 25.27 & 19.24 & 6.03 & 0.239 \\
\hline & Mean & $21.95^{*}$ & 8.36 & $271^{*}$ & $23.64^{*}$ & 17.76 & $5.88^{*}$ & $0.268^{*}$ \\
\hline & $\mathrm{SD}$ & 12.00 & 3.04 & 98 & 8.50 & 7.78 & 1.98 & 0.086 \\
\hline
\end{tabular}

$t_{1 / 2}$ : terminal serum half-life; $V_{c}:$ the apparent volume of the central compartment ;

AUC : area under the concentration-time curve ; $\mathrm{CL}:$ total clearance of vancomycin ;

$\mathrm{CL}_{\mathrm{R}}$ : renal clearance of vancomycin; $\mathrm{CL}_{\mathrm{NR}}$ : non-renal clearance of vancomycin ;

$\mathrm{CL}_{\mathrm{NR}} / \mathrm{CL}:$ the ratio of the non-renal clearance to the total clearance

* Significantly different by Wilcoxon Matched-pairs Signed-ranks Test at $\mathrm{p}<0.05$

are listed on Table 3 . The $t_{1 / 2}$ was significantly prolonged in every patient on the 10th administration from $12.99 \pm 7.11 \mathrm{hr}$ to $21.95 \pm 12.00 \mathrm{hr}$ $(\mathrm{p}<0.05)$. No significant difference for $\mathrm{Vc}$ was observed on day 1 and day 6 . CL of vancomycin significantly decreased from $35.21 \pm 13.29 \mathrm{ml} /$ min to $23.64 \pm 8.50 \mathrm{ml} / \mathrm{min}(\mathrm{p}<0.05)$, while $\mathrm{CL}_{\mathrm{R}}$ did not change between the 1st $(15.06 \pm 5.86 \mathrm{ml} /$ $\mathrm{min})$ and the 10 th $(17.76 \pm 7.78 \mathrm{ml} / \mathrm{min})$ administration. $\mathrm{CL}_{\mathrm{NR}}$ was significantly decreased in all patients from $20.15 \pm 8.45 \mathrm{ml} / \mathrm{min}$ to $5.88 \pm$ $1.98 \mathrm{ml} / \mathrm{min}(\mathrm{p}<0.05)$. The ratio of $\mathrm{CL}_{\mathrm{NR}}$ to $\mathrm{CL}$ significantly decreased from $0.568 \pm 0.067$ to $0.268 \pm 0.086 \quad(\mathrm{p}<0.05)$.

Figure 2 shows the relationship between creatinine clearance and $t_{1 / 2}$ after the 1 st $(0)$ and the 10th $(\bullet)$ dose. The regression line shifted to the right after the 10th administra- tion of vancomycin. Measured and simulated curves of vancomycin for each elderly patient based on the pharmacokinetic parameters estimated from the 1st dose are shown in Figure 3. The observed concentrations of vancomycin appeared higher than the simulated values in every patient on the last dose.

\section{Serum Protein Binding}

Serum protein binding of vancomycin was determined both in healthy subjects and in the elderly patients (Fig. 4). No significant difference was observed between the elderly patients $(50.8 \pm 6.2 \%)$ and the healthy volunteers $(45.6 \pm$ $4.0 \%)$.

\section{Discussion}

Vancomycin is not appreciably absorbed 


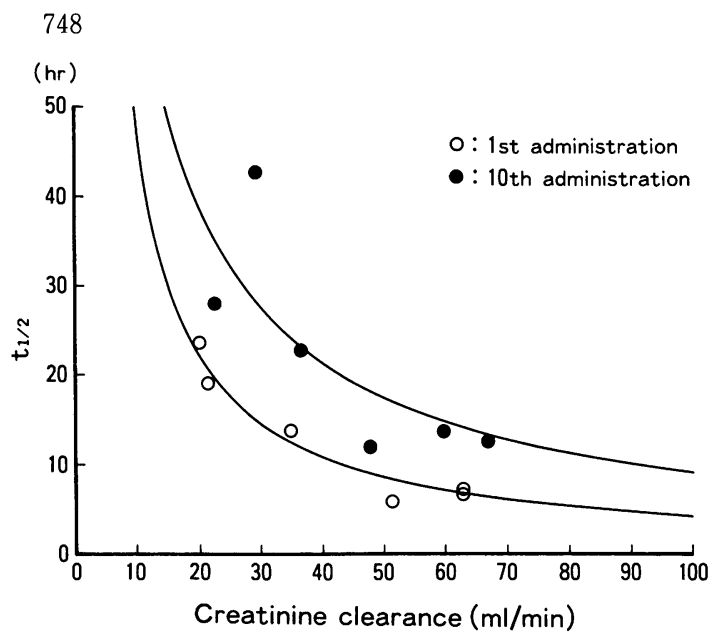

Fig. 2 Relationship between creatinine clearance and $t_{1 / 2}$ in elderly patients after the 1st $(0)$ and the 10th $(\bullet)$ administration of vancomycin.

Regression line on the 1st dose $\left(t_{1 / 2}=\right.$ $\left.0.693 /\left(1.6 \times \mathrm{CL}_{\mathrm{CR}}+0.033\right) / 10^{-3}\right)$ shifted to the right after the 10th administration $\left(\mathrm{t}_{1 / 2}=0.693 /\left(0.70 \times \mathrm{CL}_{\mathrm{CR}}+4.3\right) /\right.$ $\left.10^{-3}\right)$.

from the gastrointestinal tract when administered orally ${ }^{4,5}$. After intravenous administration, adequate therapeutic concentration of vancomycin was observed in ascitic, pericardial, pleural, and synovial fluids ${ }^{5}$. However, because of the large molecular size the drug does not pass into the spinal fluid through the normal meninges ${ }^{5}$. As previously reported, vancomycin is cleared by the kidney primarily by glomerular filtration in its active form, and does not undergo minimal metabolism ${ }^{6 \sim 8)}$. Eighty to $100 \%$ of intravenous doses of vancomycin are recovered in urine in patients with normal renal function ${ }^{1)}$. Therefore, the reduction of $\mathrm{CL}$ and the prolongation of $t_{1 / 2}$ that were observed, were due to impaired renal function ${ }^{2,3,9,10)}$. The potential for vancomycin accumulation may be high in the geriatric age group due to reduced $\mathrm{CL}^{11)}$. Careful dosing based on $\mathrm{CL}_{\mathrm{CR}}$ and serum vancomycin levels
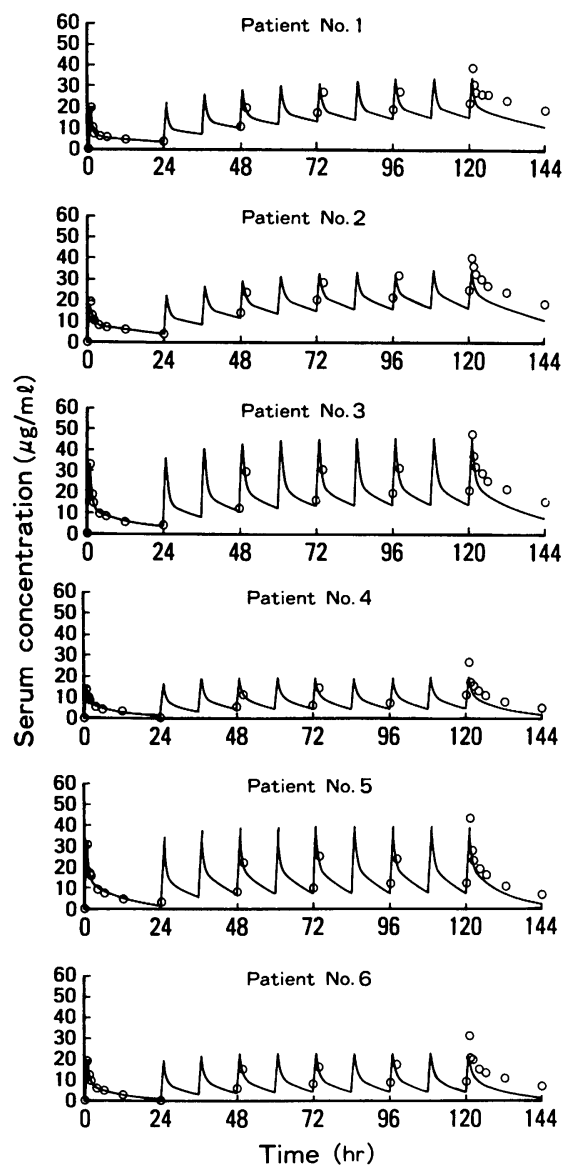

Fig. 3 Measured and simulated serum concentration-time curve of vancomycin in each patient.

The observed concentrations of vancomycin are apparently higher than the simulated curve in every patient on the last dose.

should be required and adjustment or modification of the recommended vancomycin regimen is necessary in this population to avoid the potential adverse effects associated with elevated serum concentration ${ }^{11,12)}$. Recent data suggested that serum concentrations of vancomycin of less than 25 to $50 \mu \mathrm{g} / \mathrm{ml}$ at 1 or 2 hour after infusions and trough concentrations less than $10 \mu \mathrm{g} / \mathrm{ml}$ are recommended to avoid 


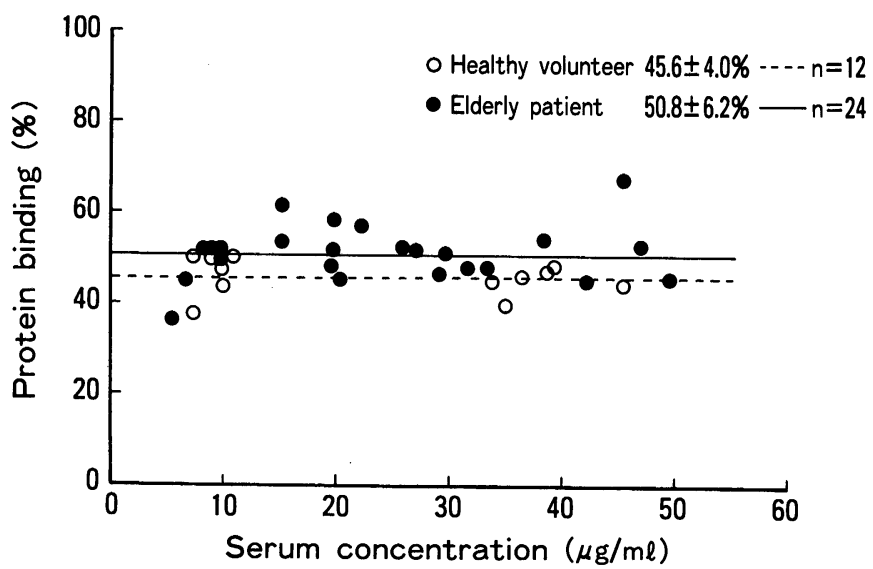

Fig. 4 Serum protein binding of vancomycin both in healthy subjects and in elderly patients.

No difference was observed between elderly patients and healthy volunteers.

adverse events such as ototoxicity and nephrotoxicity ${ }^{13 \sim 17)}$.

In the present study, $\mathrm{CL}_{\mathrm{CR}}$ of the elderly patients was much lower than that of healthy volunteers and a marked delay of elimination of the drug was observed. Healthy subjects eliminated $85.3 \pm 3.8 \%$ of the vancomycin dose in the urine during the first 24 hours, while elderly patients eliminated $32.6 \pm 8.3 \%$. Thus, $\mathrm{CL}_{\mathrm{CR}}$ is one of the major factors which influence the elimination of vancomycin.

After repeated administration non-linear pharmacokinetics were observed for elimination of vancomycin in the elderly patients: CL of vancomycin was decreased from $35.21 \pm 13.29$ $\mathrm{ml} / \mathrm{min}$ to $23.64 \pm 8.50 \mathrm{ml} / \mathrm{min}$. The $t_{1 / 2}$ of vancomycin was significantly prolonged in every patient on the 10th administration from $12.99 \pm$ $7.11 \mathrm{hr}$ to $21.95 \pm 12.00 \mathrm{hr}$, the longest value was 42.66 hours in patient No.1. Mean $C_{\max }$ increased from $22.6 \pm 7.8 \mu \mathrm{g} / \mathrm{ml}$ on day 1 to $37.8 \pm$ $8.0 \mu \mathrm{g} / \mathrm{ml}$ on day 6 . In addition, the averaged trough concentration of vancomycin was $16.7 \pm$ $6.9 \mu \mathrm{g} / \mathrm{ml}$ (range $9.1 \sim 24.7 \mu \mathrm{g} / \mathrm{ml}$ ) on day 6 ; a level above $20 \mu \mathrm{g} / \mathrm{ml}$ was observed in 3 patients. Thus, accumulation occurs during the multiple twice-daily administration of vancomycin $10 \mathrm{mg} / \mathrm{kg}$ in these elderly patients. Our data suggested that adjustment of dosing schedules may be necessary in this population to avoid the adverse events of long-term treatment.

Compared with healthy subjects, the ratio of $\mathrm{CL}_{\mathrm{NR}}$ to $\mathrm{CL}$ was much higher in the elderly patients. The reduction of $\mathrm{CL}_{R}$ of vancomycin might be compensated by $\mathrm{CL}_{\mathrm{NR}}$ in elderly patients to some extent. The extrarenal route played an important role in the elimination of vancomycin in these patients with reduced renal function. Although it has been reported that vancomycin does not undergo minimal metabolism, CL of vancomycin greater than $\mathrm{CL}_{\mathrm{CR}}$ was demonstrated in several reports ${ }^{2,18 \sim 22)}$. Rotschafer et al. demonstrated that only $50 \%$ of the variance in $t_{1 / 2}$ and $\mathrm{CL}$ is explanable by renal function and the volume of distribution ${ }^{19)}$. These investigators postulated that hepatic conjugation of vancomycin is the non-renal route of the elimination. Brown et al. also concluded that hepatic metabolism may 
play a role in vancomycin elimination ${ }^{20)}$. Furthermore, Golper et al. reported that $\mathrm{CL}_{\mathrm{NR}}$ of vancomycin in patients with normal renal function accouns for $30 \%$ of $\mathrm{CL}^{22)}$.

In the present study, $\mathrm{CL}_{\mathrm{NR}}$ of vancomycin accounted for only $6 \%$ of clearance in healthy subjects, while it accounted for $56.8 \%$ in the elderly patients.

The mechanism of increased $\mathrm{CL}_{\mathrm{NR}}$ of vancomycin in elderly patients is difficult to explain. A working hypothesis is that the impairment of renal function may lead to a compensated increase of the other elimination route, $\mathrm{CL}_{\mathrm{NR}}$. Cutler et al. investigated vancomycin pharmacokinetics in healthy elderly and young males ${ }^{12)}$. In their study, no difference was observed in the ratio of $\mathrm{CL}_{\mathrm{NR}}$ to $\mathrm{CL}$ between the two groups. They concluded that the reduction of $\mathrm{CL}$ and $\mathrm{CL}_{\mathrm{R}}$ is not correlated with renal function. However, their elderly group had almost normal $\mathrm{CL}_{\mathrm{CR}}$ (mean value was $97.7 \mathrm{ml} / \mathrm{min}$ ). In contrast, the patients in the present study had much lower $\mathrm{CL}_{\mathrm{CR}}$ (mean value was $41.9 \mathrm{ml} / \mathrm{min}$ ). Associated with the study of Cutler et al. ${ }^{12)}$, Matzke et al. suggested that the narrow range of $\mathrm{CL}_{\mathrm{CR}}$ between the two groups masked any true correlations which might be present ${ }^{11}$.

In the present study, $\mathrm{CL}_{\mathrm{NR}}$ of vancomycin significantly decreased from $20.15 \mathrm{ml} / \mathrm{min}$ to $5.88 \mathrm{ml} / \mathrm{min}$ during repeated administration in the elderly patients, even though no change was observed for $\mathrm{CL}_{\mathrm{R}}$. The decrease of $\mathrm{CL}_{\mathrm{NR}}$ was a major factor of the reduction of vancomycin $\mathrm{CL}$ after repeated administration. Macias et al. reported that early in the course of acute renal failure, $\mathrm{CL}_{\mathrm{NR}}$ of vancomycin is substantially preserved but decreased with the duration of renal failure ${ }^{23)}$. They performed repeated pharmacokinetic analyses of vancomycin in three patients receiving continuous venovenous hemofiltration. Althogh no change in $\mathrm{CL}_{\mathrm{NR}}$ was observed in one patient, a marked decrease of vancomycin $\mathrm{CL}_{\mathrm{NR}}$ occurred in the other two patients after repeated administration. Their findings of the decline in vancomycin $\mathrm{CL}_{\mathrm{NR}}$ agreed with the present results, although the disease state of patients was rather varied. The mechanism of this phenomenon was not commented upon in their report.

In the present study, no change was observed for $\mathrm{CL}_{\mathrm{CR}}$ and $\mathrm{CL}_{\mathrm{R}}$ of vancomycin after repeated administration, suggesting that the renal function and the elimination of vancomycin through the renal route could be unaffected. Golper et al. hypothesized that the mechanism of the decline in $\mathrm{CL}_{\mathrm{NR}}$ associated with long-term maintenance dialysis may be related to the inhibition of vancomycin metabolism by uremic toxins ${ }^{22)}$. However, none of the present patients suffered terminal anuric renal failure and no change was observed in blood biochemical data including blood urea nitrogen and uric acid after repeated administration. Therefore, other mechanism may have possibly played a role in the decrease in $\mathrm{CL}_{\mathrm{NR}}$ of vancomycin in our study.

If vancomycin undergoes hepatic metabolism, changes in protein binding may contribute to the decrease of $\mathrm{CL}_{\mathrm{NR}}$. However, a similar serum protein binding of vancomycin was observed in the elderly patients throughout the treatment, suggesting that protein binding does not appear to affect $\mathrm{CL}_{\mathrm{NR}}$. As other factors associated with age, sex, genetics and various pathological states may have some influence on the changes in vancomycin $\mathrm{CL}_{\mathrm{NR}}$, there are still many points to be clarified as to the mechanism of the decline in $\mathrm{CL}_{\mathrm{NR}}$ during long-term treatment in these elderly patients since $\mathrm{CL}_{\mathrm{NR}}$ of vancomycin contributes to more than $50 \%$ of vancomycin $\mathrm{CL}$ at the start of treatment. 


\section{References}

1) Kirby, W. M. M. and Divelbiss, 'C. L.:: Vancomycin : clinical and laboratory studies. Antibiot. Annu., 1956-1957 : 107-117 (1957).

2) Moellering, R. C., Krogstad, D. J. and Greenblatt, D. J. : Vancomycin therapy in patients with impaired renal function: a nomogram. Ann. Intern. Med., $94:$ 343-346 (1981).

3) Matzke, G. R., McGory, R. 'W., Halstenson, C. E. et al.: Pharmacokinetics of vancomycin in patients with various degree of renal function. Antimicrob. Agents Chemother., 25:433-437 (1984).

4) Geraci, J. E., Heliman, F. R., Nichols, D. R. et al. : Some laboratory and clinical experiences with a new antibiotic, vancomycin. Antibiot. Annu., 1956-1957 : 90-106 (1957).

5) Geraci, J. E., Heliman, F. R., Nichols, D. R. et al. : Some laboratory and clinical experiences with a new antibiotic, vancomycin. Proc. Staff Meet. Mayo Clin., 31 : 564-582 (1956).

6) Griffith, R. S. : Vancomycin : continued clinical studies. Antibiot. Annu., 1956-1957 : 118-122 (1957).

7) Lee, C. C., Anderson, R. C. and Chen, K. K. : Vancomycin, a new antibiotic. Distribution, excretion, and renal clearance. Antibiot. Annu., 1956-1957: 82-88 (1957).

8) Schaad, U. B., McCracken, G. H. and Nelson, J. D. : Clinical pharmacology and efficacy of vancomycin in pediatric patients. J. Pediatr., 96 : 119-126 (1980).

9) Cunha, B. A., Quintiliani, R., Deglin, J. M. et al. : Pharmacokinetics of vancomycin in anuria. Rev. Infect. Dis., 3 (Suppl.) : S 239-272 (1981).

10) Lam, F. Y., Lindner, A., Plorde, J. et al. : Pharmacokinetics of vancomycin in chronic renal failure. Kidney Int., 19: 152 (1981).

11) Matzke, G. R., Zhanel, G. G. and Guay, D. R. P. : Clinical pharmacokinetics of vancomycin. Clin. Pharmacokinet., $11: 257-282$ (1986).

12) Cutler, N. R., Narang, P. K., Lesko, L. J. et al. : Vancomycin disposition: the importance of age.
Clin. Pharmacol. Ther., $36: 803-810$ (1984).

13) Leach, W. : Ototoxicity of neomycin and other antibiotics. J. Laryngol. Otol., 76: 774-796 (1962)

14) Sorrell, T. C., Packham, D. R., Shanker, S. et al. : Vancomycin therapy for methicillin-resistant Staphylococcus aureus. Ann. Intern. Med., 97 : 344-350 (1982).

15) Traber, P. G. and Levine, D. P. : Vancomycin ototoxicity in a patient with normal renal function. Ann. Intern. Med., 95 : 458-460 (1981).

16) Hook, E. W. and Johnson, W. D. : Vancomycin therapy of bacterial endocarditis. Am. J. Med., 65: 411-415 (1978).

17) Farber, B. F. and Moellering, R. C. : Retrospective study of the toxicity of preparation of vancomycin from 1974 to 1981. Antimicrob. Agents Chemother., 23 : 138-141 (1983).

18) Blouin, R. A., Bauer, L. A., Miller, D. D. et al. : Vancomycin pharmacokinetics in normal and morbidly obese subjects. Antimicrob. Agents Chemother., 21 : 575-580 (1982).

19) Rotschafer, J. C., Crossley, K., Zaske, D. E. et al. : Pharmacokinetics of vancomycin : observations in twenty-eight patients and dosage recommendations. Antimicrob. Agents Chemother., 22:391-394 (1982).

20) Brown, N., Ho, D. H.W. and Fong, K-L. L. : Effects of hepatic function on vancomycin clinical pharmacology. Antimicrob. Agents Chemother., $23:$ 603-609 (1983).

21) Garaud, J. J., Regnier, B., Inglebert, F. et al. : Vancomycin pharmacokinetics in critically ill patients. J. Antimicrob. Chemother., 14 (Supp1.) : 53-57 (1984).

22) Golper, T. A., Noonan, H. M., Elzinga, L. et al. : Vancomycin pharmacokinetics, renal handling, and nonrenal clearances in normal human subject. Clin. Pharmacol. Ther. $43:$ 565-570 (1988).

23) Macias, W. L., Mueller, BA. and Scarim, S. K. : Vancomycin pharmacokinetics in acute renal failure : Preservation of nonrenal clearance. Clin. Pharmacol. Ther., 50 : 688-694 (1991). 